\title{
Pelatihan Pengolahan Sampah Botol Kaca dengan Teknik Decoupage di Desa Cibitung Wetan, Kabupaten Bogor
}

\author{
Yunita Fitra Andriana*, Bayyinah Nurrul Haq, Ulfa Septiana \\ Desain Produk, Fakultas Industri Kreatif dan Telematika, Universitas Trilogi \\ Jl. Universitas Trilogi No. 1, Kalibata, Pancoran, Jakarta Selatan \\ *Email: yunitafitra@trilogi.ac.id
}

\begin{abstract}
This community service activity, which was carried out in Desa Cibitung Wetan, Kabupaten Bogor, aims to increase the skills of housewives in processing glass bottles waste into flower vases. The Posdaya in that village has a waste bank program that has been running well. One of the programs carried out routinely at the waste bank is sorting unorganic waste that can be recycled. Even so, after this sorting process a series of further processing is needed. The method used in this activity is a short training by providing special skill, which is decoupage technique. The training started with giving demonstrations, then continued with hands-on practice and ended with discussion session. Participants in this training activity consisted of housewives who were members of Posdaya. They come from families with middle to lower economic backgrounds. The skills given in this training are expected to increase the creativity of the participants in processing waste into products with selling value, so as it is able to increase family income.
\end{abstract} Keywords
Waste Processing, Selling

\section{Value Products.}

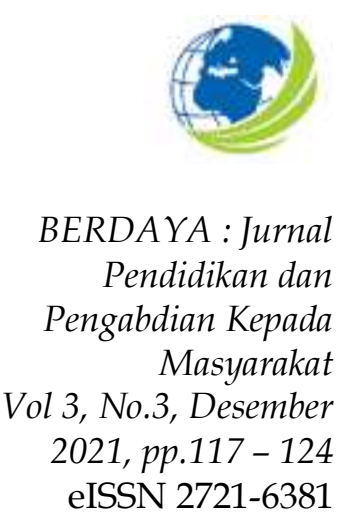

Article History

Received 22 Dec 2021 / Accepted 26 Dec 2021 / First Published: 26 Dec 2021

To cite this article

Andriana, Y., Nurrul Haq, B., \& Septiana, U. (2021). Pelatihan Pengolahan Sampah Botol Kaca dengan Teknik Decoupage di Desa Cibitung Wetan, Kabupaten Bogor. BERDAYA: Jurnal Pendidikan Dan Pengabdian Kepada Masyarakat, 3(3), 117 - 124

DOI: $10.36407 /$ berdaya.v3i3.472

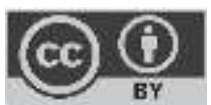

(C) The Author(s)2021

. This open access article is distributed under a Creative Commons Attribution (CC-BY) 4.0 license 
Kegiatan pengabdian kepada masyarakat yang dilakukan di Desa Cibitung Wetan, Kabupaten Bogor ini bertujuan untuk menambah keterampilan ibu-ibu rumah tangga dalam mengolah sampah berupa botol kaca menjadi vas bunga. Posdaya di Desa tersebut ini memiliki program bank sampah yang telah berjalan dengan baik. Salah satu program yang dilakukan secara rutin di bank sampah tersebut adalah pemilahan sampah kering yang dapat didaur ulang. Walaupun begitu, setelah proses pemilahan ini masih diperlukan serangkaian proses pengolahan lebih lanjut. Metode yang digunakan dalam kegiatan ini adalah pelatihan singkat dengan memberikan keterampilan khusus berupa teknik decoupage. Pelatihan diawali dengan pemberian demonstrasi, kemudian dilanjutkan dengan praktek langsung dan diakshiri dengan sesi diskusi serta tanya jawab. Peserta kegiatan pelatihan ini terdiri dari ibu rumah tangga yang merupakan anggota Posdaya. Mereka berasal dari keluarga dengan latar belakang ekonomi menengah ke bawah. Keterampilan yang diberikan pada pelatihan ini diharapkan dapat meningkatkan kreatifitas para peserta dalam mengolah sampah menjadi produk bernilai jual, sehingga dapat meningkatkan pendapatan keluarga.

Kata Kunci : Pengolahan Sampah, Produk Bernilai Jual
Yunita Fitra Andriana, Bayyinah Nurrul Haq, Ulfa Septiana

Desain Produk, Fakultas Industri Kreatif dan Telematika, Universitas Trilogi Jl. Universitas Trilogi No. 1, Kalibata, Pancoran, Jakarta Selatan

Korespondensi:

Email: yunitafitra@trilogi.ac.id

\section{PENDAHULUAN}

Posdaya atau pos pemberdayaan keluarga yang terdapat di Desa Cibitung Wetan, Kabupaten Bogor memiliki sejumlah program, salah satu programnya yang telah berjalan dengan baik adalah program bank sampah. Program ini memiliki kegiatan yang dilakukan secara rutin, misalnya pengolahan sampah organik menjadi pupuk kompos, pemilahan sampah anorganik, serta kegiatan mendaur ulang sampah anorganik tersebut. Rangkaian kegiatan bank sampah ini mampu mengurangi jumlah penumpukan sampah. Namun, laju penambahan jumlah sampah anorganik lebih cepat dibandingkan dengan proses daur ulangnya. Sehingga, diperlukan keterampilan dan kreatifitas dalam mengolah sampah anorganik tersebut agar lebih cepat terolah.

Peserta kegiatan pelatihan ini terdiri dari ibu rumah tangga yang merupakan anggota Posdaya. Mereka berasal dari keluarga dengan latar belakang ekonomi menengah ke bawah. Keterampilan yang diberikan pada pelatihan ini diharapkan dapat meningkatkan kreatifitas para peserta dalam mengolah sampah menjadi produk yang bermanfaat dan bernilai jual, sehingga dapat meningkatkan pendapatan keluarga.

Pengolahan sampah menjadi produk bernilai jual merupakan salah satu langkah dalam penerapan prinsip ekonomi sirkular. Menurut Maity (2020:238-241) konsep fundamental ekonomi sirkular adalah perluasan dari masa pakai barang. Ini adalah transisi bertahap menuju masyarakat yang berkelanjutan dengan memanfaatkan sumber daya dunia yang terbatas dan berbagai strategi yang diadopsi oleh industri untuk meregenerasi sumber 
daya secara konsisten. Ekonomi sirkular didefinisikan sebagai sistem industri yang restoratif atau regeneratif dengan niat dan desain. Konsep ekonomi sirkular terdiri dari 3 prinsip utama yaitu, merancang ulang limbah atau sampah agar bisa digunakan kembali, menggunakan produk dan material selama mungkin dan meregenerasi sistem alami (Rijksoverheid dalam Siderius, 2020:1)

\section{Sasaran Kegiatan}

Pelatihan ini diharapkan dapat menambah keterampilan para peserta sehingga mampu menghasilkan sebuah produk yang bernilai jual. Selain itu, pelatihan ini juga diharapkan dapat meningkatkan kreatifitas para peserta dalam mengolah sampah berupa botol kaca, ataupun sampah lain yang berbentuk wadah dengan permukaan rata menjadi produk yang bermanfaat.

\section{Masalah yang ingin dipecahkan}

Pengelolaan sampah merupakan permasalahan yang masih belum dapat teratasi dengan baik di Indonesia. Sedangkan timbunan sampah akan senantiasa meningkat setiap saat seiring dengan bertambahnya jumlah penduduk, perkembangan ekonomi, dan perubahan pola konsumsi ataupun gaya hidup masyarakat. Peningkatan jumlah sampah terjadi salah satunya karena peningkatan aktivitas manusia yang belum diiringi dengan kesadaran masyarakat dalam mengelola sampah (Widawati, 2019). Sampah yang tidak dikelola dengan baik akan menimbulkan sejumlah permasalahan lingkungan, diantaranya menimbulkan bau busuk, mengganggu keindahan, menyebabkan banjir, meningkatkan pemanasan iklim, memperburuk sanitasi lingkungan dan ancaman meningkatnya berbagai macam penyakit (Yudistirani dalam Widawati, 2019). Lemahnya kondisi perekonomian keluarga juga berkaitan dengan rendahnya daya dukung lingkungan dalam upaya peningkatan pendidikan menyebabkan pandangan hidup masyarakat yang pasrah dan apatis terhadap lingkungan sekitar. Dibutuhkan suatu upaya untuk membangun optimisme melalui pengalaman berkarya seni yang mampu menggugah imajinasi dan kesadaran diri dan lingkungan (Haq, 2020).

Pelatihan ini diharapkan dapat meningkatkan kesadaran masyarakat akan kelestarian lingkungan serta mengasah kreatifitas mereka dalam mengolah sampah menjadi produk bermanfaat dan bernilai jual. Bank sampah merupakan salah satu alternatif dalam strategi pengelolaan sampah (Donna dalam Pravasanti, 2020), namun masih perlu diiringi dengan keterampilan dan kreatifitas sehingga pengelolaan sampah dapat berjalan lebih baik.

\section{MATERI DAN METODE}

\section{Materi}

Materi yang diberikan pada pelatihan ini merupakan teknik decoupage, yaitu menghias benda dengan permukaan rata menggunakan kertas tissue khusus yang disebut servietten. Selain kertas tissue, dapat juga menggunakan kertas bermotif lainnya seperti kertas kado atau kertas HVS yang diprint motif di atasnya. Objek yang diaplikasikan teknik decoupage pada pelatihan ini adalah sampah botol kaca atau sampah berupa wadah yang memiliki permukaan rata atau halus, tidak bertekstur. 
Pada kegiatan ini, para peserta telah mempersiapkan sampah berupa botol kaca, toples, atau wadah yang memiki permukaan rata dan halus, tidak bertekstur. Sedangkan alat dan bahan disediakan oleh pemateri, yaitu terdiri dari:

1. Kertas tissue, pada pelatihan ini kertas tissue yang digunakan adalah kertas tissue bermotif yang mudah diperoleh di mini market atau swalayan.

2. Cat semprot untuk warna dasar, disarankan untuk menggunakan warna netral seperti putih atau hitam.

3. Gunting kertas, digunakan untuk menggunting kertas tissue sesuai motif yang diinginkan.

4. Lem kayu, digunakan untuk menempel potongan motif dari kertas tissue pada permukaan objek. Lem yang digunakan harus yang tembus pandang ketika sudah kering.

5. Kuas berukuran sedang dengan bulu kuas yang halus, digunakan untuk mengoles lem pada permukaan objek.

6. Vernish atau cat semprot clear gloss, untuk proses finishing agar objek yang sudah diberi motif dengan teknik decoupage lebih awet dan mudah dibersihkan.

7. Kertas koran bekas, digunakan untuk alas ketika mewarnai objek dengan cat dasar dan saat finishing.

\section{Lokasi dan Peserta Kegiatan}

Pelatihan ini dilaksanakan di rumah salah satu warga anggota Posdaya di Desa Cibitung Wetan, Kabupaten Bogor. Peserta merupakan ibu-ibu rumah tangga anggota Posdaya di Desa Cibitung Wetan, Kabupaten Bogor. Peserta berjumlah sekitar 30 orang dengan rentang usia 30-50 tahun.

\section{PELAKSANAAN KEGIATAN}

Pelaksanaan kegiatan dibagi menjadi 3 tahap, yaitu tahap persiapan, tahap menghias dan tahap finishing. Pada setiap tahapan, dilakukan demonstrasi terlebih dahulu baru selanjutnya diikuti oleh seluruh peserta. Berikut merupakan pelaksanaan kegiatan di lapangan:

\section{Tahap persiapan:}

Pada tahap ini, sampah dicuci bersih lalu dikeringkan. Pastikan seluruh permukaan objek bersih dan tidak bertekstur. Warnai objek dengan warna dasar yang diinginkan, lebih baik gunakan warna netral seperti putih atau hitam. Pada tahapan ini gunakan cat semprot, pastikan warna yang dihasilkan merata. Jemur hingga kering.

\section{Tahap menghias:}

Gunting motif yang ada pada kertas tissue atau kertas kado. Motif harus digunting dengan rapi dan sesuai garis luarnya. Tata seluruh potongan motif di atas objek hingga membentuk komposisi yang baik. Oleskan lem putih di bagian belakang potongan motif lalu tempel di atas objek. Lapisi bagian atas motif dengan olesan lem putih, lakukan berulang. 
Yunita Fitra Andriana et al.

Waste Processing, Selling Value Products

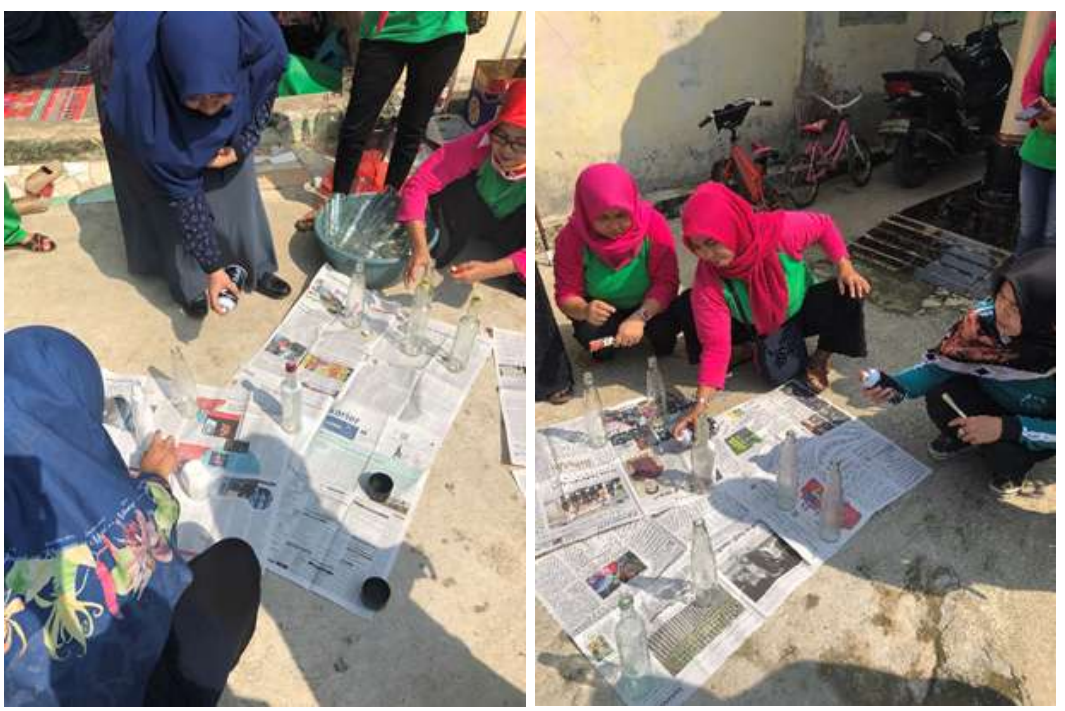

Gambar 1. Kegiatan

Pelatihan pada Tahap

Persiapan. Sumber: Dok.

Penulis

Sumber: Dokumentasi Tim Pelaksana

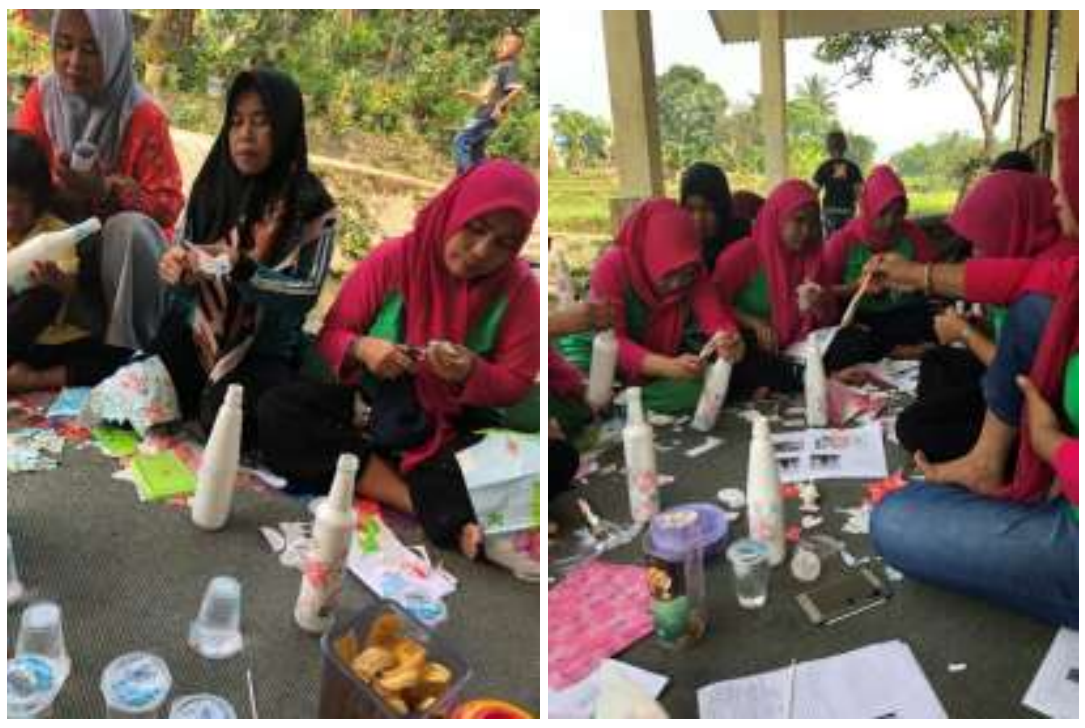

Sumber: Dokumentasi Tim Pelaksana
Gambar 2. Kegiatan Pelatihan pada Tahap Menghias. Sumber: Dok. Penulis

\section{Tahap finishing:}

Tunggu lapisan lem putih hingga kering, lalu semprot menggunakan cat clear atau varnish. Jemur hingga kering, vas bunga siap digunakan. 


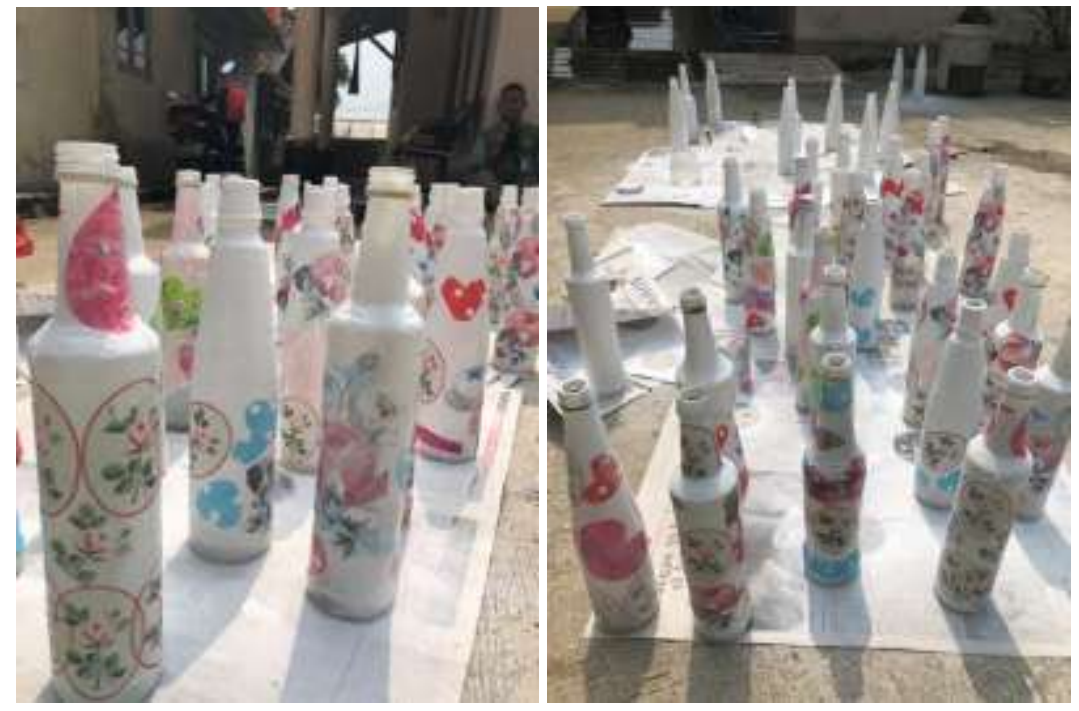

Sumber: Dokumentasi Tim Pelaksana
Gambar 3. Kegiatan Pelatihan pada Tahap Finishing. Sumber: Dok. Penulis

\section{Evaluasi Kegiatan}

Pada pelatihan ini materi yang diberikan hanya tentang bagaimana menghias objek menggunakan teknik decoupage saja. Materi tentang bagaimana cara menyusun komposisi motif yang baik tidak diberikan. Hal ini mengakibatkan hasil karya peserta dari segi estetika masih kurang baik. Selama kegiatan pelatihan berlangsung, peserta sangat antusias dan bersemangat. Terlebih lagi, teknik decoupage ini termasuk teknik menghias yang mudah dan hasilnya cepat terlihat.

\section{KESIMPULAN}

Kesimpulan yang dapat ditarik dari pelatihan ini di antaranya adalah, warga anggota Posdaya memerlukan keterampilan dan upaya untuk mengasah kreatifitas dalam mengolah sampah. Respon peserta sangat antusias dan tertarik untuk mempelajari keterampilan baru. Peserta yang didominasi oleh para ibu rumah tangga memerlukan keterampilan sederhana yang bisa menggunakan alat dan bahan yang mudah ditemukan di sekitar mereka. Selain itu, para peserta juga membutuhkan keterampilan yang mudah dan cepat, tidak memakan waktu lama untuk memperoleh hasil akhirnya.

Tingkat ketercapaian kegiatan pengabdian masyarakat tidak dapat diukur dengan menggunakan angka (Astuti dalam Ajisukmo, 2019). Oleh karena itu, ketercapaian dari pelatihan ini adalah bertambahnya keterampilan dan wawasan peserta, dari yang sebelumnya tidak mengetahui teknik decoupage menjadi tahu, dari yang tidak menguasai teknik decoupage menjadi menguasai.

\section{Saran kegiatan Lanjutan}

Saran dan rekomendasi untuk kegiatan selanjutnya adalah pengenalan komposisi motif sederhana yang sesuai dengan prinsip dasar desain, serta pengenalan kombinasi warna yang secara visual baik. Selain itu, perlu dilakukan pelatihan bisnis, penentuan budgeting hingga harga. Lebih jauh lagi perlu dilakukan pelatihan fotografi produk dan cara menjual barang dagangan di online market place serta menjajakannya di social media seperti Instagram, Facebook dan Tiktok. 


\section{REFERENSI}

Ajisukmo, C., R., P., \& Iustitiani, N., S., D., \& Pramono, H. (2019). Pelatihan Kerajinan Decoupage Sebagai Cara untuk Menumbuhkan Budaya Literasi Kaum Perempuan. Abdimas Dewantara Volume 2, No. 2, Oktober 2019, 158-170

Asteria, Donna dan Heru Heruman. 2016. Bank Sampah Sebagai Alternatif Strategi Pengelolaan Sampah Berbasis Masyarakat Di Tasikmalaya. Jurnal Manusia Dan Lingkungan, 23 (1): 136-141

Astuti, E.Z.L.\& Winarni, T. (2018). Mendorong partisipasi Bina Keluarga Lansia (BKL) dalam mewujudkan tujuh dimensi lansia tangguh di Desa Sumbersari, Moyudan, Sleman. Jurnal Pengabdian Kepada Masyarakat, 3(2), 130-142.

Haq, B., N., \& Kharishma, V., \& Krishnamurti, M., I. (2020). Pelatihan Melukis dengan Cat Air untuk Siswa Rumah Pintar Anak Pesisir Muara Angke. Jurnal Pengabdian Masyarakat J-DINAMIKA, Vol. 5, No. 2, Desember 2020, 39-45

Maity, Subhankar \& Singha, Kunal \& Pandit, Pintu \& Ray, Amal. (2020). Circular Economy in Fashion and Textile From Waste. Scrivener Publishing LLC, John Wiley \& Sons

Pravasanti, Y., A., \& Ningsih, S. (2020). Bank Sampah untuk Peningkatan Pendapatan Ibu Rumah Tangga. Jurnal BUDIMAS Vol. 02, No. 01, 2020, 31-35

S.A. Yudistirani, L. Syaufina, S. Mulatsih. (2015). Desain Sistem Pengelolaan Sampah Melalui Pemilahan Sampah Organik dan Anorganik Berdasarkan Persepsi Ibu-Ibu Rumah Tangga, Jurnal Konversi, Vol 4 (2)

Siderius T, Poldner K. (2021). Reconsidering The Circular Economy Rebound Effect: Propositions from a case study of the Dutch Circular Textile Valley. Journal of Cleaner Production

Widawati, A., S., \& Ikmah. (2019). Pemberdayaan Masyarakat dalam Pengelolaan Sampah Rumah Tangga. Seminar Hasil Pengabdian Masyarakat 2019, UNIVERSITAS AMIKOM Yogyakarta, 30 November 2019.

\section{About the Authors}
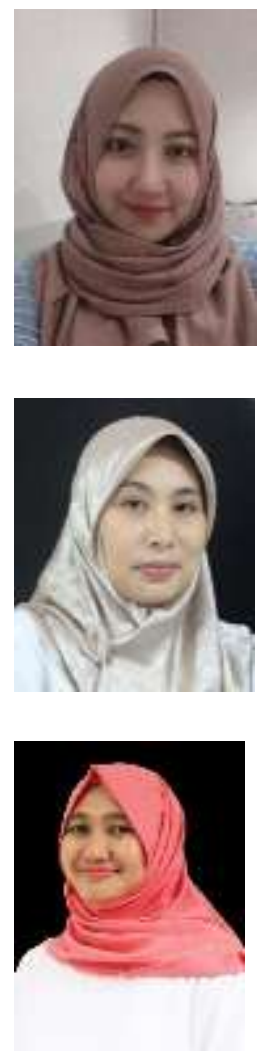

Yunita Fitra Andriana, S.Ds., M.Ds. Kelahiran Bandung, 8 Juni 1987. Merupakan dosen program studi Desain Produk Universitas Trilogi sejak 2013. Bidang keahliannya adalah kriya tekstil dan fashion. Email: yunitafitra@trilogi.ac.id

Bayyinah Nurrul Haq, S.Sn., M.Pd. Kelahiran Bandung, 25 Juni 1979. Merupakan dosen program studi Desain Produk Universitas Trilogi sejak 2014. Bidang keahliannya adalah Desain Produk Industri dan Pendidikan Seni. Email: bayyinah.nh@trilogi.ac.id

Ulfa Septiana, S.Sn., M.Ds. Kelahiran Bogor, 13 September 1985. Merupakan dosen program studi Desain Produk Universitas Trilogi sejak 2014. Bidang keahliannya adalah kriya tekstil dan fashion. Email: ulfa.hadi@gmail.com 


\section{DECLARATIONS}

\section{Funding}

Seluruh kegiatan pengabdian kepada masyarakat ini didanai oleh RISTEKDIKTI tahun 2019

\section{Competing Interests}

Penulis menyatakan bahwa tidak ada konflik kepentingan yang diungkapkan. 